\title{
CERVICAL LENGTH AND PHOSPHORILATED INSULIN LIKE GROWTH FACTOR BINDING PROTEIN-1 AS THE PREDICTORS OF SPONTANEUS PRETERM DELIVERY IN SYMPTOMATIC WOMEN
}

\author{
Hadži-Lega Marija, ${ }^{1}$ Daneva Markova Ana, ${ }^{1}$ Stefanovic Milan ${ }^{2}$ \\ ${ }^{1}$ University Clinic of Obstetrics \& Gynecology, Medical Faculty, Ss. Cyril and Methodius University, \\ Skopje, Republic of Macedonia \\ ${ }^{2}$ Departments of Obstetrics \& Gynecology, Medical Faculty Nis, Republic of Serbia
}

Primljen/Received 16. 04. 2014. god.

Abstract: Objective: To assess the combined use of cervical length and cervical phosphorylated insulin-like growth factor binding protein-1 (phIGFBP-1) in the prediction of preterm delivery in symptomatic women in next 14 days.

Methods: Cervical length was prospectively measured in 58 consecutive singleton pregnancies with intact membranes and regular contractions at 24-36 weeks, and phIGFBP-1 was assessed. Demographic data was evaluated(history of previous preterm delivery,history of spontaneous abortion,parity,BMI,maternal age, Orthodox or Muslims).

Results: Values of all variables were evaluated (demographic data, cervical length and values of phIGFBP-1) alone and in combination with cervical length of $\leq 15 \mathrm{~mm}$ and more than $15 \mathrm{~mm}$.

In women with cervical length less than $15 \mathrm{~mm} /$ /phIGFPB-1 was positive in 30 patients (22 of them delivered in 14 days). In women with cervical length less than $15 \mathrm{~mm} / \mathrm{phIGFBP}-1$ was positive in 9 of delivered pregnant women in 14 days. In women with cervical length less than $25 \mathrm{~mm} / \mathrm{phIGFBP}-1$ was positive in 26 patients ( 2 of them delivered in 14 days). In patients with cervical length more than $25 \mathrm{~mm} / \mathrm{ph}$ IGFBP-1 was positive in 4 patients ( 2 of them delivered in 14 days). With logistic regression we confirmed that with OR 0.117 and CI $95 \%(0.046-0.295)$ and $p<0.01$ odds for preterm birth among patients with negative phIGFBP-1 is 0.117 lower than the odds for preterm birth among patients with positive test results. With same test for $p=0.009(p<0.01)$ we confirmed with OR and CI 95\% (0.06 to 0.671) that cervical length less
Prihvaćen/Accepted 10. 06. 2014. god.

than $25 \mathrm{~mm}$ is good predictor of preterm delivery with symptomatic patients.

Probability for delivery in the following 14 days with patients with positive phIGFBP-1and cervical length $\leq 15 \mathrm{~mm}$ is 0.88 or probability for not delivering in those patients is 0.12 . In $88 \%$ patients with positive phIGFBP- 1 and cervical length $\leq 15 \mathrm{~mm}$ will deliver in the following 14 days.

Conclusions: In symptomatic women phIGFBP-1 may significantly improve the risk assessment for preterm delivery with cervical length and help to plan subsequent pregnancy management.

Key words: Preterm labor, transvaginal ultrasound, predictive value, sensitivity, specifies.

\section{INTRODUCTION}

Preterm delivery is the leading cause of neonatal mortality and morbidity. Consequently, women presenting with threatened preterm labor are often treated with hospitalization and the administration of tocolytics to avoid preterm delivery. Randomized studies on the use of tocolytics in threatened preterm labor have demonstrated a significant prolongation of pregnancy by about 7 days but no significant reduction in the incidence of preterm delivery, perinatal morbidity or mortality $(1,2)$.

Only a minority of the women presenting with threatened preterm delivery will actually deliver preterm (3). Given the side effects of tocolysis and the costs of hospital admission, a proper and correct diagnosis of impending preterm delivery is crucial. In the last years, 
there have been attempts to identify, among women presenting with uterine contractions, the subgroup with the highest risk of delivering preterm. There is a wealth of literature suggesting that cervical length measured by ultrasound and fetal fibronectin has the potential to improve the prediction of preterm delivery $(4,5,6)$.

In order to institute more appropriate specific therapy, it is importantto have adjuvant tests to help predicting who is most likely to have a pretermdelivery. The detection of phIGFBP-1 incervical secretion of women presenting with preterm labor has been shown to be associated with an increased risk of preterm delivery $(7,8,9)$.

Insulin-like growth factor binding protein-1 (IGFBP-1) is a $28-\mathrm{kDa}$ hydrophobic protein which is non-glycosylated and binds and regulates the function of insulin-like growth factors. Amniotic fluid contains little of the phosphorylated iso-forms of IGFBP-1, while tissues produce mainly phosphorylated forms (phIGFBP-1). IGFBP-1 levels in amniotic fluid are 100-1000 times higher than in serum and are essentially undetectable in other body fluids. The phosphorylated IGFBP-1 iso-forms are predominantly secreted by human decidual cells. IGFBP-1 and phIGFBP-1 can be differentiated by the use of specific monoclonal antibodies (10). Consequently, the presence of IGFBP-1 can be used to detect preterm rupture of membranes (PROM) (10), while the presence of phIGFBP-1 in cervical secretions reflects decidual activation (11). Recently, cervicovaginal concentrations of phIGFBP-1 have been shown in correlation with the risk of preterm delivery (12-24). Disruption to the choriodecidual interface results in elevated levels in cervical secretions. Potentially contaminating body fluids with fetal fibronectin (fFN), such as semen and urine, contain only trace quantities of $p h$ IGFBP-1 (10). A commercial bed side test kit is available to detect Phosphorylated insulin-like growth factor binding protein-1 (phIGFBP-1) in cervical secretions of women presenting with threatened preterm labor. The ActimPartus test (MedixBiochemica, Kauniainen, Finland) is an immunochromatographic dipstick test based on monochromal antibodies for $p h \mathrm{IGFBP}-1$. The test is similar in principle to a urine pregnancy test and does not require technical expertise. The cost per test is approximately one quarter that of fFN.

Available research suggested that a negative phIGFBP-1 test would rule out imminent delivery in $\sim 90$ to $95 \%$ of patients (25-29). The negative predictive value (NPV) of phIGFBP-1 was therefore felt to be comparable to $\mathrm{fFN}$, although there was little evidence directly comparing the two tests in the same population (30).

The purpose of present study was to evaluate the combination of cervical length measurement and cer- vicovaginal phIGFBP-1 as prediction factor of preterm delivery within 14 days in symptomatic patients.

\section{METHODS}

\section{Population study}

58 pregnant women were eligible to join the study if they attended the University Clinic for Gynecology and Obstetrics, Skopje and were admitted to Department of High Risk pregnancy Unit with symptoms of preterm labor (symptoms of uterine activity judged by the assessing physician to be indicative of preterm labor) at 24 to 36 weeks gestation. They were recruited in period of 6 months, from September 2013 till March 2014. They were with symptoms or complaints suggestive of preterm labor including uterine contractions, intermittent lower abdominal pain and pelvic pressure. Recruited patients had intact amniotic membranes determined by speculum examination and minimal cervical dilatation $(\leq 3 \mathrm{~cm})$. Women were excluded if they had ruptured membranes, antepartum hemorrhage, active labor, gestational hypertension, preeclampsia, multiple gestation, a cervical cerclage in place and suspected chorioamnionitis (defined by fever, abdominal pain, leukocytosis).

Consenting women were treated according to usual hospital protocol, with addition ofvaginal swabs taken for phIGFBP-1. Women were asked to empty their bladders and were placed in dorsal lithotomy position. An ultrasound probe was inserted into the vagina, with ultrasound gel applied only between the probe and the probe cover, and not on the external surface of the probe cover. The probe was placed in the anterior fornix, and the cervical length was measured as previously described (31).

With these women, a commercially available immunochromatography - based rapid strip test (ActimPartus Test; MedixBiochemica, Kauniainen, Finland) was used to detect phIGFBP-1 in cervical secretions. After sterile speculum introduction prior to ultrasound or digital examination sample of cervical fluid was collected from the external os with a Dacron swab provided in the test package. After collection, the swab was immediately transferred to a specimen extraction solution (bovine albumin and protease inhibitors in $0.5 \mathrm{ml}$ phosphate solution) and the sample extracted by shaking for $10 \mathrm{~s}$. An immunochromatography dipstick was placed in the solution for five minutes before analyzing the result. The minimum detectable concentration was $10 \mu \mathrm{g} / \mathrm{ml}$, although a concentration of $30 \mu \mathrm{g} / \mathrm{ml}$ was required for positive result, which appeared as two blue lines on the test dipstick. A negative result appeared as a single blue line. As vaginal bleeding and amniotic fluid could produce false positive results, patients with 
these conditions were excluded from the study. Urine or seminal liquid did not interfere with the test result. All women gave their written informed consent, and the study was approved by the local Ethical Committee. The managing clinician was aware of cervical length measurements, but blinded to phIGFBP-1 results.

After collection of the cervical sample, a transvaginal ultrasound measurement was performed using 6.5 MHz transvaginalprobe according to the Fetal Medicine Foundation Criteria (32). The mean of three measurements was used. A digital examination of the cervix was then performed and cervical status documented according to the modified Bishop score. A 30-minute cardiotocogram was performed and uterine contractions recorded. Urine analysis was performed in all cases to exclude urinary tract infection. Tocolysis with beta mimmetics was used according to clinical protocols and steroids were administrated as appropriate.

Outcome variable was occurrence of preterm delivery within 14 days from the day of hospital admission.

\section{Statistical analysis}

IBM SPSS Statistics 20 was used for analysis. Test for logistic regression (binary) and receiver operating characteristic curves (ROC) were used, p-values < 0.05 were considered as significant.

\section{RESULTS}

The main demographic characteristics of the study population are shown in Table 1. Mean maternal age was 30.12 . Mean gestational age was 31.55 at recruitment. Mean height was 164.34. Mean weight was 74.05. Mean BMI was 27.54. From 58 women, with history of previous preterm delivery were 10 . We also evaluated number of previous spontaneous abortion, parity and smoking, Muslims or Orthodox at patients with threatened preterm labor.

Table 1. Demographic characteristics of study population $(n=58)$

\begin{tabular}{|c|c|}
\hline & Mean \pm SD (range) \\
\hline Maternal age (years) & $30.12 \pm 4.82(20-40)$ \\
\hline Gestation age at examination & $31.55 \pm 3.95(22-36)$ \\
\hline BMI & $27.54 \pm 4.93(18.7-43.8)$ \\
\hline \multicolumn{2}{|l|}{$\mathrm{n}(\%)$} \\
\hline \multicolumn{2}{|l|}{ Parity } \\
\hline Nuliparous & $13(22.41)$ \\
\hline Multiparous & $45(77.59)$ \\
\hline Previous preterm delivery & $10(17.24)$ \\
\hline Smoker & $11(18.96)$ \\
\hline
\end{tabular}

Table 2. Prevalence and rate of cervical length, phIGFBP-1 at study entry and delivery according the outcome $(n=58)$

\begin{tabular}{|l|c|c|}
\hline & N & $\%$ \\
\hline Cervical length $\leq 15$ & 14 & 24.1 \\
\hline Cervical length $15-25$ & 23 & 39.6 \\
\hline Cervical length $>25$ & 21 & 36.2 \\
\hline phIGFBP-1 $(+)$ & 30 & 51.7 \\
\hline Delivery in $<7$ days & 24 & 41.6 \\
\hline Delivery in $7-14$ days & 11 & 18.9 \\
\hline
\end{tabular}

Note: phIGFBP-1, phosphorylated insulin growth factor binding protein-1

Values of all variables which were evaluated, demographic data, cervical length and values of phIGFBP-1 alone and in combination with cervical length of $\leq 15$ $\mathrm{mm}$ and more than $15 \mathrm{~mm}$, are shown in Table 2 . phIGFPB-1 was positive in 30 patients (22 of them delivered in 14 days). In women with cervical length less than $15 \mathrm{~mm}$ phIGFBP-1 was positive with 9 of delivered pregnant women in 14 days. In women with cervical length less than $25 \mathrm{~mm}$ phIGFBP was positive with 26 patients (20 of them delivered in 14 days). In patients with cervical length more than $25 \mathrm{~mm}$ phIGFBP-1 was positive with 4 patients ( 2 of them delivered in 14 days).

With logistic regression we confirmed that with OR 0.117 and CI 95\% (0.046-0.295) and $\mathrm{p}<0.01$ odds for preterm birth among patients with negative phIGFBP-1 is smaller (0.117) than the odds for preterm birth among patients with positive test results. With same test $(\mathrm{p}<0.01)$, we confirmed $\mathbf{O R}=\mathbf{1 4 . 7 2 2}$ and CI $95 \%$ (5.273 to 41.104)that cervical length less than $25 \mathrm{~mm}$ is good predictor of preterm delivery with symptomatic patients.

With statistical analysis we find predictive formula for prediction of preterm delivery in the following 14 days by combination of cervical length and phIGFBP-1. Formula for prediction if delivery in next 14 days by cervical length $<15 \mathrm{~mm}$ and positive phIGFBP-1 is calculated like:

In $($ odds of preterm birth $)=0.186+0.829 \times(\mathrm{ac}-$ timpartus $)+1.437 \times($ cervical length $<15 \mathrm{~mm})=2.08$

$P($ preterm birth $)=1 /\left(1+\mathrm{e}^{- \text {(ln (odds of preterm birth) }}\right)=1 /(1$ $\left.+\mathrm{e}^{-2,08}\right)=1 / 1+0.1249=1 / 1.1249=0.88$.

(e - basis of the natural logarithm $\left(\ln =\log _{e}\right)$, e $=\mathbf{2 7 1 8 2 8 1 8 2 8 4 5 9} \ldots=\mathbf{2 . 7 1 8}$ )

It means that probability for delivery in the following 14 days with patients with positive phIGFBP-1 and cervical length $\leq 15 \mathrm{~mm}$ is 0.88 or probability for not delivering with that patients is 0.12 .In $88 \%$ patients with positive phIGFBP-1 and cervical length $\leq 15 \mathrm{~mm}$ will deliver in the following 14 days. 
Formula for prediction of delivery in the following 14 days by combination of cervical length $<25 \mathrm{~mm}$ and positive phIGFBP-1:

In (odds of preterm birth) $=-0.754+0.593 \times$ (acimpartus) $+1.399 \times$ (cervical length $<25 \mathrm{~mm})=$ 1.238

$P($ preterm birth $)=1 /\left(1+\mathrm{e}^{-(\text {lnodds of preterm birth) }}\right)=$ $1 /\left(1+\mathrm{e}^{-1.238}\right)=0.775$

It means that probability for delivery in the following 14 days with patients with positive phIGFBP-1 and cervical length $<25 \mathrm{~mm}$ is 0.76 or probability for not delivering with that patients is 0.24 . Thus, $76 \%$ of the patients with positive phIGFBP-1 and cervical length $<25 \mathrm{~mm}$ will deliver in the following 14 days.

By logistic regression we evaluated prediction of delivery in next 14 days by history of previous preterm delivery, $\mathrm{p}$ is not significant $(\mathrm{p}=0.2)$ and model is working with $62 \%$ accuracy, so history of previous preterm delivery is not a good predictor of preterm delivery in the following 14 days. We also evaluated history of

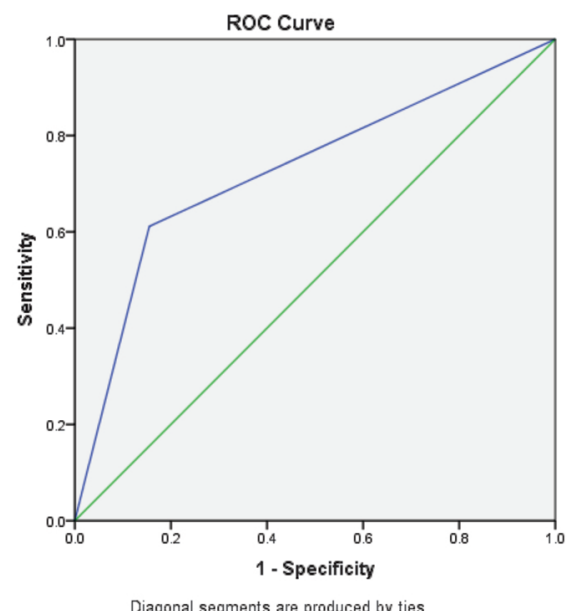

Figure 1. ROC curve of Actimpartus test performance as individual predictor in preterm delivery

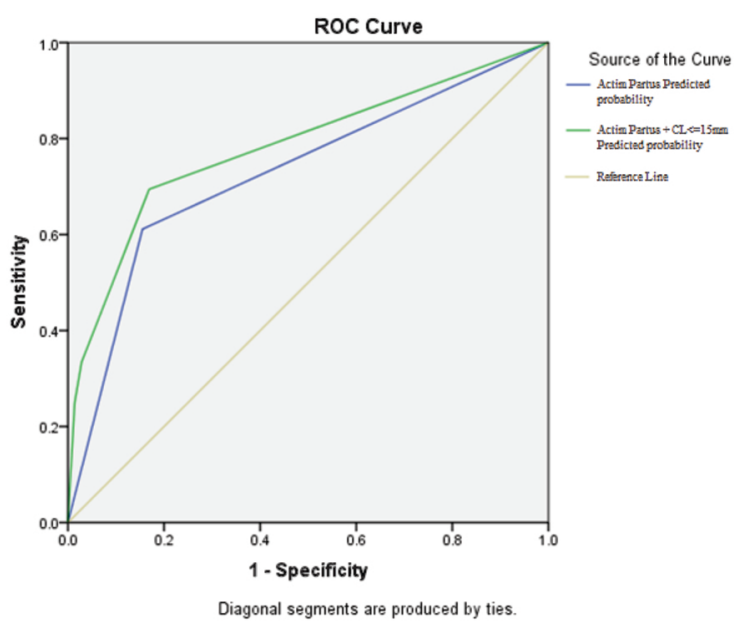

Figure 2. ROC curves for the performance of combinations of Actimpartus test and length of cervix $C L \leq 15 \mathrm{~mm}$ as predictors of preterm birth

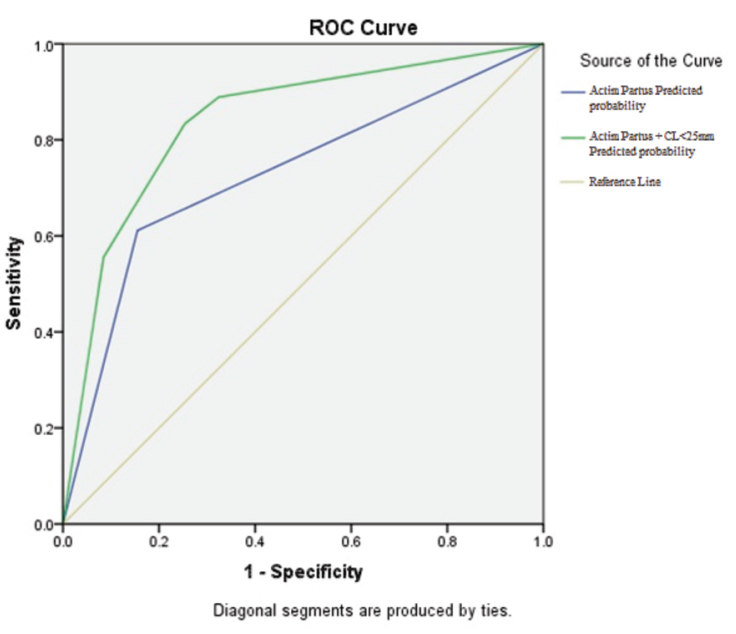

Figure 3. ROC curves for the performance of combinations of Actimpartus test and length of cervix $C L<25$ mmas predictors of preterm birth

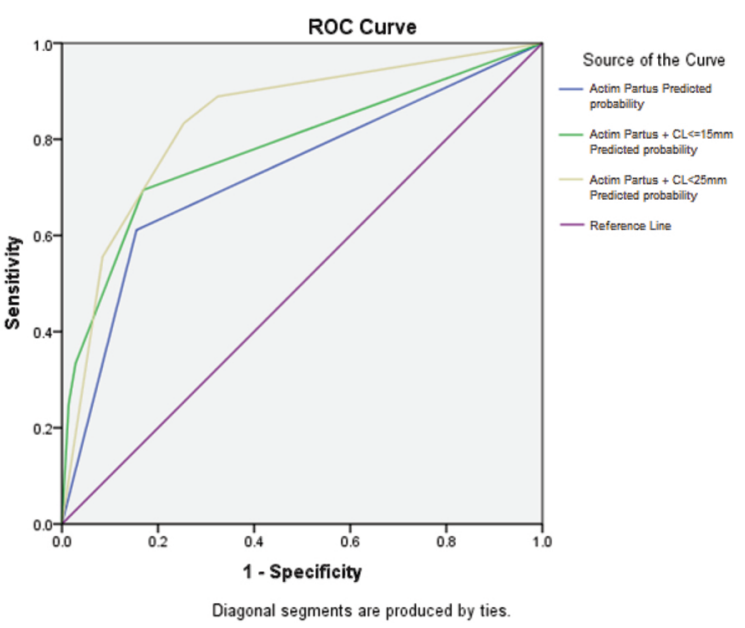

Figure 4. ROC curves for the performance of combinations ofActim partus test, Actim partus test and $C L \leq 15 \mathrm{~mm}$ and Actim partus test and $C L<25 \mathrm{~mm}$

previous spontaneous abortion, parity, smoking, BMI, vaginal ph and none of them separately is a good predictor for delivery in next 14 days ( $\mathrm{p}$ is not significant). The addition of a positive phIGFBP-1 to cervical length $\leq 15$ or $25 \mathrm{~mm}$ improve accuracy of the predictive value of isolated cervical length.

ROC curves of Actimpartus test performance as individual predictor in preterm delivery is shown in Figure 1. ROC curves for using cervical length to predict delivery in the following 14 days showed a cervical length of $\leq 25 \mathrm{~mm}$ and Actimpartus as giving an area under the curve (AUC) of $0.667(0.517-0.817, \mathrm{p}<0.05)$ (Figure 3). ROC curves were significant for cervical length $\leq 25 \mathrm{~mm}$ in prediction of delivery in next 14 days. ROC curves for using positive Actimpartusto predict delivery in the following 14 days showed a positive Actimpartusas giving an area under curve (AUC) 


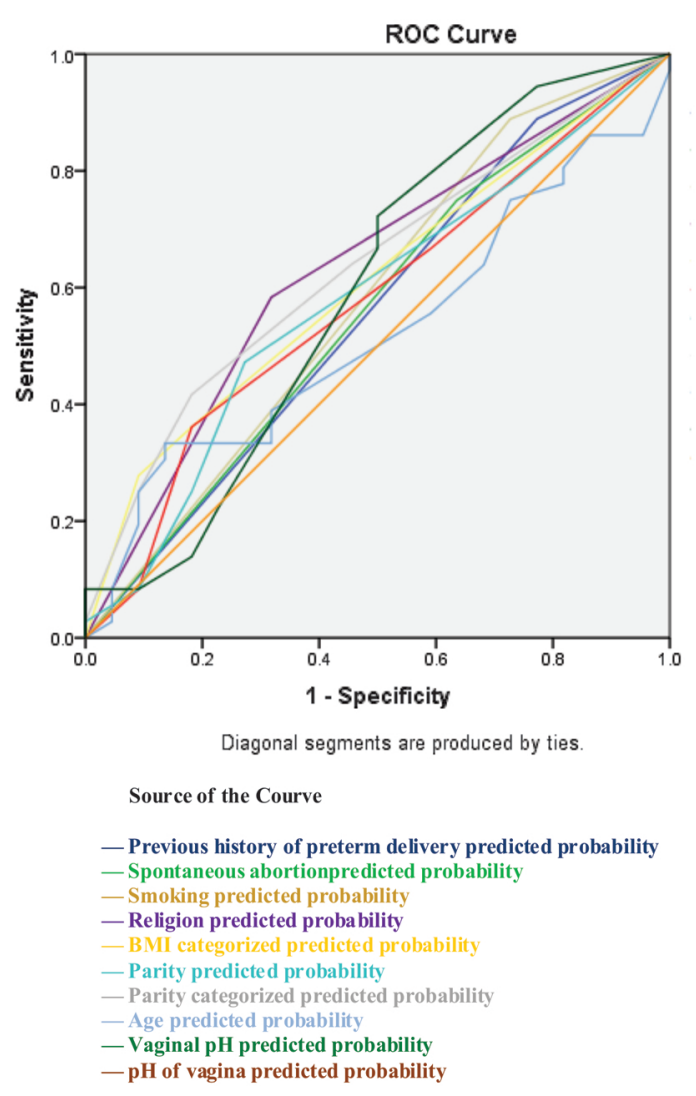

Figure 5. ROC curves for the performance of other variables tested for ability of prediction of preterm labor

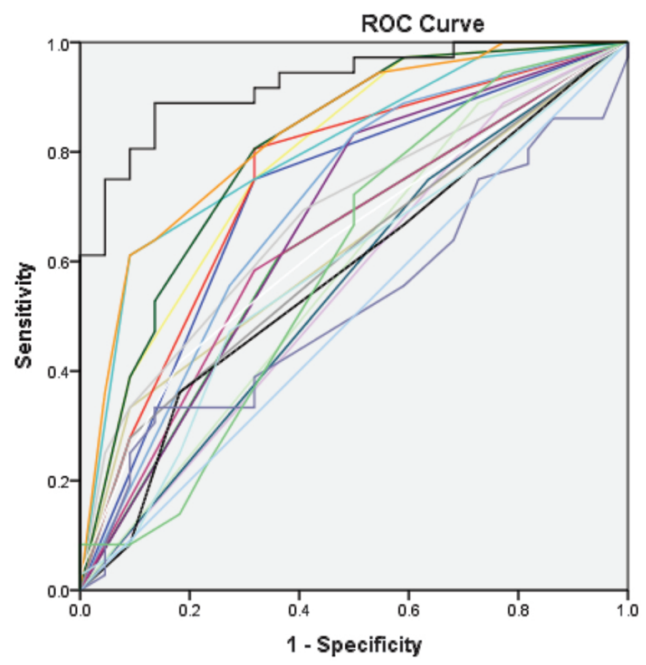

Diagonal segments are produced by ties. Source of the Courve

- Previous history of preterm delivery predicted probability - Spontaneous abortion predicted probability

- Smoking predicted probability

- Religion predicted probability

- BMI categorized predicted probability

- Parity predicted probability

- Parity categorized predicted probability

- Age predicted probability

- Vaginal $\mathrm{pH}$ predicted probability

$-\mathrm{pH}$ of vagina predicted probability

- actimpartus + cervical length less than $25 \mathrm{~mm}$ predicted probability

- actimpartusprobabilityvalue

-actimpartus + cervical length less than $15 \mathrm{~mm}$ predic ted probability

Figure 6. ROC curves for the performance of all variables tested for ability of prediction of preterm delivery of $0.624(0.474-0.773, p>0.05)$. ROC curves were not significant for positive phIGFBP alone as a predictor for delivery in next 14 days. ROC curves for using cervical length $\leq 15 \mathrm{~mm}$ and $\leq 25 \mathrm{~mm}$ in combination of positive Actimpartus showed them as giving an area under curve (AUC) of $0.683(0.545-0.821, \mathrm{p}<0.05)$ and $0.698(0.554-0.843, p, 0.05)$ (Figure 4). So, both combination of cervical length $\leq 15 \mathrm{~mm}$ and cervical length $\leq 25 \mathrm{~mm}$ with positive Actimpartus are good prediction model of delivery in next 14 days (Figure 4). ROC curves for other variables which were evaluated for prediction of delivery in the following 14 days (history of preterm delivery, history of spontaneous abortion, parity, BMI, ph of vagina, Orthodox or Muslims) showed that area under curve (AUC) are between 0.5 to 0.6 and $p>0.05$. They are not good predictors for delivery in next 14 days (Figure 5). In the Figure 6 are shown all evaluated predictors in ROC curve.

\section{DISCUSSION}

Despite advances in obstetric care, preterm delivery remains a major cause of neonatal morbidity and mortality. With women presenting an acute risk of preterm delivery, tocolysis, steroids and in utero transfer to a center with neonatal intensive care are recommended (33). This involves unnecessary treatment and complex management in a relevant number of symptomatic women who eventually will not deliver preterm. Therefore, there is a need for assessment tools to reliably identify cases who are at highest risk of early delivery, and those who are not and can avoid treatment. Cervical length measurement by transvaginal ultrasound and assessment of fibronectin in cervical secretion are the most extensively studied prognostic factors in cases of threatened preterm delivery (34). Cervicovaginal fibronectin is estimated to have a positive and negative likelihood ratio of 4.10 and 0.35 , respectively, in the prediction of delivery within 7-10 days, while the same values for a cervical length measurement of $15 \mathrm{~mm}$ are 8.61 and 0.03 (34). However, given the clinical significance of the risk of a false negative diagnosis, i.e. the risk of not appropriately treating a pregnancy which is going to deliver within a few days, there have been various attempts to combine cervical length and fibronectin assessment in a single or two-step test, with discordant results $(4,35-40)$. phIGFBP-1 appears to have a similar accuracy to fibronectin, with a positive and negative likelihood ratio of 3.29 and 0.20 , respectively, in the prediction of delivery within 7 days, a positive and negative likelihood ratio of 2.53 and 0.32 , respectively, in the prediction of delivery within 48 hours (34). As well as fibronectin, phIGFBP-1 is commercially available as a bed-side test, and is approximately $50 \%$ cheaper. 
Some recent studies evaluated a combination of cervical length and phIGFBP-1 in the prediction of preterm delivery in symptomatic women. Eroglu et al. (20) assessed 51 cases between 24 and 35 weeks of gestation. These authors reported an increase in specificity and positive predictive value by combining phIGFBP-1 with cervical length. However, the sensitivity reported for phIGFBP-1 alone $(>80 \%)$ was similar to that described by the same and other groups $(15,16)$, but appreciably higher than what was reported by others $(8,21)$ and found in our series. This variability may be explained by the small absolute number of events in each study, as well by differences in case selection criteria. Paternoster et al. (23) studied 210 women with a singleton pregnancy with documented uterine contractions and intact membranes between 24 and 34 weeks' gestation. They found that a cervical length of $d<26$ $\mathrm{mm}$ and a positive phIGFBP-1 have an odds ratio of 16 and 9 for preterm delivery before 37 weeks, respectively. Rahkonen et al. (24) examined 246 symptomatic women between 22 and 34 weeks of gestation, among which 10 (4.1\%) delivered before 34 weeks. They found that a short cervix $(<25 \mathrm{~mm})$, a positive phIGFBP-1 test, and a combination of both were associated with preterm delivery $\leq 34$ weeks or within 14 days $(p<$ $0.01)$. The negative predictive values for delivery $\leq 34$ weeks were 97.4, 97.6, and 97.1, respectively, and within 14 days 98.7, 99.0, and 98.3, respectively.

Our study concentrated on the most clinically relevant forms of preterm delivery, i.e. those deliveries taking place within 14 days from presentation. We confirmed that the majority of pregnant women presenting with threatened preterm labor potentially undergoes unnecessary treatment very few will delivery within 14 days (only 36). PhIGFBP-1alone is not a good predictor for delivering in next 14 days but combination of cervical length $(\leq 15 \mathrm{~mm}, \leq 25 \mathrm{~mm})$ with phIGFBP-1 is a good predictor. It means that probability for delivery in the following 14 days in patients with positive phIGFBP- 1 and cervical length $\leq 15 \mathrm{~mm}$ is 0.88 or probability for not delivering in those patients is 0.12 . In $88 \%$ patients with positive phIGFBP-1 and cervical length $\leq 15 \mathrm{~mm}$ will deliver in the following 14 days. Attention was paid to avoid any bias in phIGFBP-1 results related to the sampling methodology. The cervical rather than vaginal approach was chosen, as it was likely to provide more robust results as recently demonstrated (36). No ultrasound gel was used on the probe cover for the transvaginal ultrasound examination, and all digital cervical examinations were performed after sampling for phIGFBP-1, as their effect on testing results is unclear. Vaginal bleeding, which may give false positive results, was a criterion for patient exclusion (36).

Attention was paid to avoid any bias in phIGFBP-1 results related to the sampling methodology. The cervical rather than vaginal approach was chosen, as it was likely to provide more robust results as recently demonstrated (24). No ultrasound gel was used on the probe cover for the transvaginal ultrasound examination, and all digital cervical examinations were performed after sampling for phIGFBP-1, as their effect on testing results is unclear. Vaginal bleeding, which may give false positive results, was a criterion for patient exclusion (24).

In this study, the managing clinician was aware of cervical length measurements, but blinded to phIGFBP-1 results. This is likely to have affected the decision to use corticosteroids and tocolysis, and consequently have influenced the final incidence of preterm delivery with the different subgroups.

\section{CONCLUSION}

Finally, testing the value of the combination of phIGFBP-1 and cervical length allow us to find prediction model based on logistic regression analysis. Again, our study population was too small to allow such an approach. However, the combined use of phIGFBP-1 and cervical length with symptomatic women might have the potential for decreasing the false positive diagnoses of impending preterm delivery, allowing therefore to reduce the biological and economic costs of inappropriate treatment.

Other demographic data (history of previous preterm delivery, history of spontaneous abortion, parity, BMI, Orthodox or Muslims, vaginal $\mathrm{Ph}$ ) are not good predictors for delivery in the following 14 days.

\section{Abbreviations}

phIGFBP-1 - phosphorylated insulin-like growth factor binding protein-1

BMI - Body mass index

OR - Odds ratio

CI - Confidence interval

PROM - Premature rupture of membranes

ROC - Receiver operating characteristic 


\title{
Sažetak
}

\section{DUŽINA CERVIKSA I phIGFBP-1 (PHOSPHORILATED INSULIN LIKE GROWTH FACTOR BINDING PROTEIN-1) KAO PREDIKTORI SPONTANOG PREVREMENOG POROĐAJA KOD SIMPTOMATSKIH ŽENA}

\author{
Hadži-Lega Marija, ${ }^{1}$ Daneva Markova Ana, ${ }^{1}$ Stefanovic Milan ${ }^{2}$ \\ ${ }^{1}$ University Clinic of Obstetrics \& Gynecology, Medical Faculty, Ss. Cyril and Methodius University, \\ Skopje, Republic of Macedonia \\ ${ }^{2}$ Departments of Obstetrics \& Gynecology, Medical Faculty Nis, Republic of Serbia
}

Cilj: proceniti kombinovanu upotrebu dužine cerviksa i phIGFBP-1 kao prediktora spontanog prevremenog porođaja kod simptomatskih žena u toku narednih 14 dana.

Metodologija: dužina cerviksa i phIGFBP-1 su prospektivno mereni kod 58 uzastopnih jednoplodnih trudnoća 24-36 nedelje, sa intaktnim plodovim ovojnicama i regularnim kontrakcijama. Evaluirani su demografski podaci (istorija prethodnih prevremenih porođaja, paritet, BMI, godine starosti majke, veroispovest) i izvršena odgovarajuća statistička analiza.

Rezultati: evaluirane su vrednosti svih varijabli (demografski podaci, dužina grlića i vrednosti phIGFBP-1), pojedinačno i u odnosu na dužinu cerviksa $\leq 15 \mathrm{~mm}$ i više od $15 \mathrm{~mm}$.

Kod žena sa dužinom cerviksa manjom od 15 mm/phIGFPB-1 je bio pozitivan kod 30 pacijentkinja

\section{REFERENCES}

1. Tanir HM, Sener T, Yildiz Z. Cervical phosphorylated insulin-like growthfactor binding protein-1 for the prediction of preterm delivery insymptomatic cases with intact membranes. $\mathrm{J}$ Obstet Gynaecol Res. 2009; 35(1): 66-72.

2. King J F, Grant A, Keirse M, Chalmers I. Beta-mimetics in preterm labour: an overview of the randomized controlled trials. Br J Obstet Gynaecol. 1988; 95: 211-22.

3. McPheeters ML, Miller WC, Hartmann KE et al. The epidemiology of threatened preterm labor: a prospective cohort study. Am J Obstet Gynecol. 2005; 192(4): 1325-9.

4. Gomez R, Romero R, Medina L et al.Cervicovaginal fibronectin improves the prediction of preterm delivery based on sonographic cervical length in patients with preterm uterine contractions and intact membranes. Am J Obstet Gynecol. 2005; 192(2): 350-9.

5. Kagan KO, To M, Tsoi E, Nicolaides KH. Preterm birth: the value of sonographic measurement of cervical length BJOG. 2006; 113 (Suppl 3): S52-6.

6. Smith V, Devane D, Begley CM, Clarke M, Higgins S. A systematic review and quality assessment of systematic reviews of fetal fibronectin and transvaginal length for predicting preterm birth. Eur J Obstet Gynecol Reprod Biol. 2007; Aug 133(2): 134 42.

7. Altinkaya O, Gungor T, Ozat M, Danisman N, Mollamahmutoglu L.Cervical phosphorylated insulin-like growth factor binding protein-1 inprediction of preterm delivery. Arch Gynecol Obstet. 2009; 279(3): 279-83.

8. Kekki M, Kurki T, Karkkainen T, Hiilesmaa V, Paavonen J, Rutanen EM. Insulin-like growth factor-binding protein-1 in cervical secretion as a predictor of preterm delivery. Acta Obstet Gynecol Scand. 2001; 80(6): 546-51. (njih 22 su se porodile za 14 dana). Logističkom regresijom potvrdili smo da sa OR 0.117 i CI 95\% (0.046$0.295)$ i $\mathrm{p}<0.01$, šansa za prevremni porođaj među pacijentkinjama sa negativnim phIGFBP-1 je 0.117 niža nego šansa za prevremni prođaj među pacijentkinjama sa pozitivnim rezultatom. Istim testom za $\mathrm{p}=0.009(\mathrm{p}$ $<0.01)$ potvrdili smo sa OR i CI $95 \%$ (0.06 to 0.671$)$ da je dužina grlića manja od $15 \mathrm{~mm}$ dobar prediktor za prevremeni porođaj kod simptomatskih žena. $88 \%$ pacijentkinja sa pozitivnim phIGFBP-1 i cervikalnom dužinom $\leq 15 \mathrm{~mm}$ će se poroditi u narednih 14 dana.

Zaključak: Kod simptomatskih žena, phIGFBP-1 i dužina cerviksa, mogu značajno poboljšati procenu rizika za prevremeni porođaj i pomoći u daljem planiranju tretmana trudnoće.

Ključne reči: prevremeni porođaj, transvaginalni ultrazvuk, dužina cerviksa, phIGFBP-1.

9. Lembet A, Eroglu D, Ergin T et al. New rapid bed-side test to predict preterm delivery: phosphorylated insulin-like growth factor binding protein-1 in cervical secretions. Acta Obstet Gynecol Scand. 2002;81(8):706-12.

10. Balic D, Latifagic A, Hudic I. Insulin-like growth factor-binding protein-1(IGFBP-1) in cervical secretions as a predictor of preterm delivery. J Matern Fetal Neonatal Med. 2008; 21(5): 297-300.

11. Abenhaim HA, Morin L, Benjamin A. Does availability of fetal fibronectintesting in the management of threatened preterm labour affect theutilization of hospital resources? J Obstet Gynaecol Can. 2005; 27(7): 689-94.

12. Abenhaim HA, Morin L, Benjamin A. Does availability of fetal fibronectintesting in the management of threatened preterm labour affect theutilization of hospital resources? J Obstet Gynaecol Can. 2005; 27(7): 689-94.

13. Kekki M, Kurki T, Karkkainen T, Hiilesmaa V, Paavonen J, Rutanen EM. Insulin-like growth factor-binding protein-1 in cervical secretion as a predictor of preterm delivery. Acta Obstet Gynecol Scand. 2001; 80(6): 546-51.

14. Kurkinen-Raty M, Ruokonen A, Vuopala S, et al. Combination of cervical interleukin- 6 and -8 , phosphorylated insulin-like growth factor-binding protein-1 and transvaginal cervical ultrasonography in assessment of the risk of preterm birth. BJOG. 2001;108 (8): 875-81.

15. Lembet A, Eroglu D, Ergin T, et al. New rapid bed-side test to predict preterm delivery: phosphorylated insulin-like growth factor binding protein-1 in cervical secretions. Acta Obstet Gynecol Scand. 2002; 81(8): 706-12. 
16. Kwek K, Khi C, Ting HS, Yeo GS. Evaluation of a bedside test for phosphorylated insulin-like growth factor binding protein-1 in preterm labour. Ann Acad Med Singapore. 2004; 33(6): 780-3.

17. Akercan F, Kazandi M, Sendag F, et al. Value of cervical phosphorylated insulin like growth factor binding protein-1 in the prediction of preterm labor. J Reprod Med. 2004; 49 (5): 368-72.

18. Elizur SE, Yinon Y, Epstein GS, Seidman DS, Schiff E, Sivan E. Insulin-like growth factor binding protein-1 detection in preterm labor: evaluation of a bedside test. Am J Perinatol. 2005 ; 22(6): 305-9.

19. Bittar RE, da Fonseca EB, de Carvalho MH, Martinelli $\mathrm{S}$, Zugaib M. Predicting preterm delivery in asymptomatic patients with prior preterm delivery by measurement of cervical length and phosphorylated insulin-like growth factor-binding protein-1. Ultrasound Obstet Gynecol. 2007; 29(5): 562-7.

20. Eroglu D, Yanik F, Oktem M, Zeyneloglu HB, Kuscu E. Prediction of preterm delivery among women with threatened preterm labor. Gynecol Obstet Invest. 2007; 64(2): 109-16.

21. Paternoster DM, Muresan D, Vitulo A, et al. Cervical phIGFBP-1 in the evaluation of the risk of preterm delivery. Acta Obstet Gynecol Scand. 2007; 86(2): 151-5.

22. Ting HS, Chin PS, Yeo GSH, Kwek K. Comparison of bedside test kits for prediction of preterm delivery: phosphorylated insulin-like growth factor binding protein-1 (pIGFBP-1) test and fetal fibronectin test. Ann Acad Med Singapore. 2007; 36(6): 399-402.

23. Paternoster D, Riboni F, Vitulo A, et al. Phosphorylated insulin-like growth factor binding protein-1 in cervical secretions and sonographic cervical length in the prediction of spontaneous preterm delivery. Ultrasound Obstet Gynecol. 2009; 34(4): 437-40.

24. Rahkonen L, Unkila-Kallio L, Nuutila M, Sainio S, et al. Cervical length measurement and cervical phosphorylated insulin-like growth factor binding protein-1 testing in prediction of preterm birth in patients reporting uterine contractions. Acta Obstet Gynecol Scand. 2009; 88(8): 901-8.

25. Goldbenberg RL. The management of preterm labor. Obstet Gynecol. 2002;100(5 Pt 1): 1020-37.

26. Akercan F, Kazandi M, Sendag F, et al. Value of cervical phosphorylated insulinlike growth factor binding protein-1 in the prediction of preterm labor. J Reprod Med. 2004; 49 (5): 368-72.

27. Elizur SE, Yinon Y, Epstein GS, Seidman DS, SchiV E, Sivan E. Insulin-like growth factor binding protein-1 detection in preterm labor: evaluation of a bedside test. Am J Perinatol. 2005 ; 22(6): 305-9.

28. Kwek K, Khi C, Ting HS, Yeo GS. Evaluation of a bedside test for phosphorylated insulin-like growth factor binding protein-1 in preterm labour.Ann Acad Med Singapore. 2004; 33: 780-3.

\section{Correspondence to/Autor za korespondenciju}

\section{Marija Hadži-Lega, MD}

Department of Obstetrics and Gynecology

State University Hospital of Skopje

Street Vodnjanska; number 17, 100 Skopje, Macedonia marijahadzilega@yahoo.com; mobile ++ 38978485580

Ana Daneva Markova, MD

Department of Obstetrics and Gynecology

State University Hospital of Skopje

Street Vodnjanska; number 17, 100 Skopje, Macedonia anadaneva@yahoo.com: mobile ++38970 71471

Milan Srefanovic, Phd, MD

Department of Obstetrics and Gynecology

State University Hospital of Nis

mila9@open.telekom.rs
29. Lembet A, Eroglu D, Ergin T, et al. New rapid bed-side test to predict preterm delivery: phosphorylated insulin-like growth factor binding protein-1 in cervical secretions. ActaObstetGynecol Scand. 2002; 81(8): 706-12.

30. Ting H-S, Chin PS, Yeo G, Kwek K. Comparison of bedside test kits for prediction of preterm delivery: phosphorylated insulin-like growth factor binding protein-1 (pIGFBP-1) test and fetal fibronectin test. Ann Acad Med Singapore. 2007; 36 (6): 399-402.

31. Sonek J, Shellhaas C. Cervical sonography: a review. Ultrasound Obstet Gynecol. 1998; 11(1): 71-8.

32. Paternoster DM, Muresan D, Vitulo A, et al. Cervical phIGFBP-1 in the evaluation of the risk ofpreterm delivery. Acta Obstet Gynecol Scand. 2007;86(2):151-5.

33. Iams JD, Romero R, Culhane JF, Goldenberg RL. Primary, secondary, and tertiary interventions to reduce the morbidity and mortality of preterm birth. Lancet. 2008; 371(9607): 164-75.

34. Honest H, Forbes CA, Duree KH, et al. Screening to prevent spontaneous preterm birth: systematic reviews of accuracy and effectiveness literature with economic modelling. Health TechnolAssess. 2009; 13(43): 1-627.

35. Schmitz T, Maillard F, Bessard-Bacquaert S, et al. Selective use of fetal fibronectin detection after cervical lengthmeasurement to predict spontaneous preterm delivery in women withpreterm labor. Am J Obstet Gynecol. 2006; 194(1): 138-43.

36. Elizur SE, Yinon Y, Epstein GS, Seidman DS, SchiffE, Sivan E.Insulin-like growth factor binding protein-1 detection in preterm labor:evaluation of a bedside test. Am J Perinatol. 2005; 22(6): 305-9.

37. Rozenberg P, Goffinet F, Malagrida L, et al. Evaluating the risk of preterm delivery: a comparison of fetal fibronectin and transvaginalultrasonographic measurement of cervical length. Am J Obstet Gynecol. 1997; 176(1): 196-9.

38. Hincz P, Wilczynski J, Kozarzewski M, Szaflik K. Two-step test: the combined use of fetal fibronectin and sonographic examination of the uterine cervix for prediction of preterm delivery in symptomatic patients. Acta Obstet Gynecol Scand. 2002; 81(1): 58-63.

39. Tsoi E, Akmal S, Geerts L, Jeffery B, Nicolaides KH. Sonographic measurement of cervical length and fetal fibronectin testing in threatened preterm labor. Ultrasound Obstet Gynecol. 2006; 27(4): 368-72.

40. Gomez R, Romero R, Medina L,et al. Cervicovaginal fibronectin improves the prediction of preterm deliverybased on sonographic cervical length in patients with preterm uterinecontractions and intact membranes. Am J Obstet Gynecol. 2005; 192(2): 350-9 